\title{
Productivity Assessment (Performance, Motivation, and Job Training) using Profile Matching
}

\author{
Hasrul Azwar Hasibuan ${ }^{1}$, Rahima Br. Purba ${ }^{2}$, Andysah Putera Utama Siahaan ${ }^{3}$ \\ ${ }^{1,2}$ Faculty of Economics and Business \\ ${ }^{3}$ Faculty of Computer Science \\ Universitas Pembangunan Panca Budi \\ Jl. Jend. Gatot Subroto Km. 4,5 Sei Sikambing, 20122, Medan, Sumatera Utara, Indonesia
}

\begin{abstract}
A good company gives an opportunity for employees to develop their creativity through new ideas of employees. Any opinions, thoughts or ideas are the results of ideas. There is a process of reflection on an opinion or an idea that emerged at the head of the employee. But not all employees who have a brilliant idea. There are some among them who are not motivated to have a good performance. Three factors influence the employee reputation. Performance, motivation, and job training are the essential things to do by the company to raise the reputation. Each employee level can be calculated by Profile Matching method. It produces the value of each employee or ranks them in ascending or descending order. The benefit to the company is they can promote the best employees in particular period.
\end{abstract}

Keywords - Productivity, Assessment, Profile Matching

\section{INTRODUCTION}

The development of globalization has made many companies have qualified personnel. Companies are required to be able to maximize employee performance. Not all staff have a good working. The Company must assess the factors that may affect employee performance. Human resources are the main things that must be considered and developed. The presence of both the human resources and professional will assist in maximizing the performance of a company. It affects the progress of the company. If the performance of a company is not good, it will hinder the progress of the company.

No maximum performance generated by employees is due to the lack of motivation to work. Work motivation is encouragement, the driving force or forces that cause an action or deed [6]. Motivation will give a boost to perform better activities than ever before. Motivation means the way or technique. A person commits an act have a motive. The basic motive of the person is the person's needs will be the pride and honor as well, may be material. One's motivation is the driving force that will realize a behavior to achieve the goal. People want to work to make ends meet, both the needs of the conscious and the need or desire is not realized. Sometimes people work to have the physical and mental needs. Good motivation will be very useful to build awareness, disciplined and professional.

Employee performance is influenced by good motivation from superiors or his partner.For example, when the break had expired but there are still employees who have not re-entered the office. Lack of motivation, it makes the lack of awareness of the employee's job responsibilities. It can be overcome by giving lessons to them and help them comply with the rules contained in the company. To overcome this, providing motivation to employees is needed to make their work more structured and focused. Good motivation will greatly help in the development of employee performance itself. A real impact for the company is the company's reputation will increase.

This study was conducted to examine the employee rate by calculating several factors that affect employee performance. The assessment problem can be solved by using profile matching method. Profile matching is to sort data from low to high or vice versa. It calculates several parameters determined previously and finds the gap between the target and the raw data. The result is expected to conduct an assessment of the employee. If the employee has a low value, a company can make improvements.

\section{A. Productivity}

\section{THEORIES}

Employee performance is important in increasing the employee productivity. In improving employee performance, companies must be able to determine the factors that can affect the performance. Job performance is the result of the quality and quantity of work accomplished by an employee in carrying out duties by the responsibilities given. Performance is a result of work achieved in executing the tasks assigned to them based on skills, experience, and seriousness [1][6]. From some views on the notion of 
performance, according to experts, it is concluded that the performance of employees is the work of employees of a company to achieve the goals or targets that have been set in a specific period.

\section{B. Motivation}

Work motivation is as a stimulus for someone to do a good job; it is also a factor that makes the difference between success and failure in work. Many things are critical for any work to be carried out. Motivation is the drive of the individual to perform certain actions based on their needs. The motivation of individuals can be understood as an encouragement to achieve the objectives of the company and himself. Motivation usually arises because of the unfulfilled needs or needs that can not be fulfilled [7]. This requirement will cause pressure and stress that will create a boost or an attempt to meet these requirements. These needs can be satisfied then the individual will experience a drop in pressure.

\section{Profile Matching}

Profile matching is a very important process in human resource management which is determined beforehand competencies required for the job. Competence is a requirement that candidates for office holders must have [3]. In a profile matching process outlines a process of comparing the individual competencies into job competency that can be known differences in competence (gap) [4][5]. The smaller the gap is generated then the weight value, the greater meaning it has a greater opportunity for employees to take that position.To analyze the employees by specific occupations carried out by the method of profile matching, which in the process is first to determine the competence require. Profile matching process is the process of comparing the individual's competence in job competency so that can know the difference competence.

Profile Matching process is divided into several stages [2]:

- Aspect and Sub Aspect

- Scoring

- Gap

- Core Factor \& Secondary Factor

- Total Weight

- Result

Gap is the difference between the value of the aspect and the target value. It can be obtained by this formula.

$$
\text { Gap }=\text { Aspect Value }- \text { Target Value }
$$

Core and Secondary Factor are calculated by these formulas.

$$
\begin{aligned}
& N C F=\frac{\sum_{i=1}^{n} N C}{\sum_{i=1}^{n} I C} \\
& N S F=\frac{\sum_{i=1}^{n} N S}{\sum_{i=1}^{n} I S}
\end{aligned}
$$

$\begin{array}{lll}\text { NCF } & : & \text { Core Factor Value } \\ \text { NSF } & : & \text { Secondary Factor Value } \\ \text { NC } & : & \text { Total Weight Core Factor } \\ \text { NS } & : & \text { Total Weight Secondary Factor } \\ \text { IC } & : & \text { Total Item Core Factor } \\ \text { IS } & : & \text { Total Item Secondary Factor }\end{array}$

\section{MethodologY}

Giving the right motivation will be very helpful in the course of the employee and the results achieved. Motivation is a state of psychological and mental attitude gives energy, encouragement or direction, behaviors towards achieving satisfaction. The award of work on employee motivation will improve skills, skills, experience, and determination of work, so as to achieve maximum work. Giving responsibility, challenge, direction and opportunity will motivate employees to excel. The importance of motivation for employees is very helpful in solving the problems faced by the employees confidentially. Increasing employee motivation will improve employee performance.

\section{A. Motivation Types}

To increase the performance of employees, it is required special techniques that can lead to awareness of quality. There are two methods offered, direct and indirect methods.

\section{Direct Motivation}

This method is a material, or non-material motivation is provided directly to an individual for the fulfillment and satisfaction. This motivation can be realized for example by giving praise, rewards, bonuses and awards.

2. Indirect Motivation

This method is the motivation that a facility with the intent to support and bolster morale and smooth the task. For example, giving a comfortable work space, the creation of ambiance and good working conditions.

\section{B. MeasurementFactors}

There are several factors to measure the work motivation. These factors are as a determinant of the (1)success of an employee in performing work activities. These factors are: 
1. Objective

Someone who has a high motivation to work has a strong incentive to achieve maximum performance, which will affect the objectives of a company or agency.

2. Morale

Morale as a good psychological state when morale raises pleasure that encourages a person to work harder and better and consistent in achieving the goals set by the company or agency.

\section{Initiative and creativity}

Initiative is defined as the power or ability of an employee or an employee to begin or continue a job full of energy without any encouragement from others or on their own will, while creativity is the ability of employees or employees to find new relationships and make combinations new. Something new does not mean that was not there before, but something new this may be something that has not been previously known.

\section{Sense of responsibility}

The attitude of individual employees who have a good motivation to work must have a sense of responsibility towards the work they do so that the work can be completed on-time

\section{Job Training}

Job training improves employee job. It will greatly help the employees themselves to be able to work and innovate better. The training is a learning process to obtain the skills, concepts, rules, or attitude to improve employee performance. Through vocational training, the ability of employees will be increased. The work is charged on each employee is expected to be finished soon with satisfactory results. Therefore, vocational training also plays a major role in improving the capability and performance generated by employees. The performance produced by the employee will be better and the maximum.

Implementation of job training intended to obtain employment who have the knowledge, skills, ability and a good attitude to fill positions available jobs with high labor productivity, which can produce good work. The need for each worker is very diverse, for the vocational training needs to be prepared and implemented by the field work. Thus the job at hand will be done smoothly by the correct procedure. There are four factors that influence the result of job training.

\section{Knowledge}

That knowledge is all the property or the contents of the mind. Knowledge is the result of the process of human endeavor. In the dictionary of philosophy, explained that knowledge is a process of life known to man directly from his consciousness. In this event who know have known in itself so active so knowing that compose known to himself in the unity of the active. So with enough knowledge will help finish the job done quickly and with good results.

2. Ability

The ability is an activity of reasoning that reflective, critical, and creative, which is oriented at an intellectual process that involves the formation of the concept, application, analysis, assessing the information collected or generated by observation, experience, reflection, communication as a basis for a conviction and action. Thinking is the activity of the human person which lead to the invention directed to a destination. We think to find an understanding that we will. With the capability commensurate with the work performed, the work will yield maximum results and good.

3. Attitude

The attitude is as an evaluative statement, both pleasant and unpleasant towards objects, people, or events. It reflects how someone about something. Defines attitude as something propensity to respond consistently to support or not support certain about the object. Good attitude in the face of a problem will help in the smooth running of the work performed.

4. Skill

Skill is a skill that allows someone to get a job or to be able to keep working, including personal skills, interpersonal skills, attitudes, habits, and behaviors. Skills possessed an employee in implementing its duties will affect the results he gets later.

\section{Assessment}

The instrument is a tool used to measure the natural and social phenomena are observed. Instruments in this study was a questionnaire containing questions that need to be answered and filled out by the respondents. The questionnaire contained questions about work motivation, job training, and employee performance. The data in this study is quantitative, by distributing questionnaires to the respondents. Respondents were asked to make an assessment of work motivation, job training, and employee performance. Table 1 shows the modeling of the instruments used. 
Table 1 Assessment instrument

\begin{tabular}{|c|l|}
\hline Variable & \multicolumn{1}{|c|}{ Instrument } \\
\hline \multirow{4}{*}{$\begin{array}{c}\text { Employee } \\
\text { performance }\end{array}$} & $\begin{array}{l}\text { Effectiveness and } \\
\text { efficiency }\end{array}$ \\
\cline { 2 - 2 } & Orientation \\
\cline { 2 - 2 } & Discipline \\
\cline { 2 - 2 } Work motivation & Initiative \\
\cline { 2 - 2 } & Objectives \\
\cline { 2 - 2 } & Responsibility \\
\hline \multirow{4}{*}{ Job training } & Knowledge \\
\cline { 2 - 2 } & Ability \\
\cline { 2 - 2 } & Attitude \\
\cline { 2 - 2 } & Prowess \\
\hline
\end{tabular}

Table 2 Scoring system

\begin{tabular}{|c|c|}
\hline Remark & Score \\
\hline Disagree & 1 \\
\hline Neutral & 2 \\
\hline Agree & 3 \\
\hline
\end{tabular}

In preparing the research instruments, the writer refers to the Likert Scale. It is a psychometric scale commonly used in the questionnaire and the scale of the most widely used in the form of survey research. When responding to questions in the Likert Scale, respondents specify their level of agreement to a statement by choosing one of the options available. Table 2 shows there are three ranges of scale in this assessment, disagree, neutral and agree.The employee can answer the question given by choosing one of the options listed on the questionnaire. There is no compulsion in answering the questions. The answer is the actual truth in the hearts of each employee.

\section{EVALUATION}

This section shows the illustration of the Profile Matching calculation. Assume there are five employees those will be rated. The following table shows five employees have been mapped into the scoring system. The credit value is between " 1 " and "3". Number "1" is the lowest value while the number " 3 " is the highest one.
Table 3Scoringdata

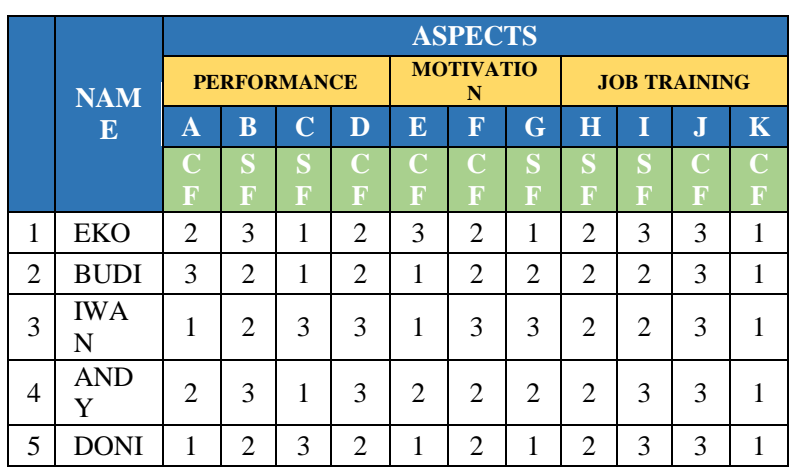

Table4: Target Value

\begin{tabular}{|l|l|l|l|l|l|l|l|l|l|l|l|}
\hline Target & 2 & 2 & 2 & 2 & 1 & 1 & 1 & 2 & 2 & 2 & 2 \\
\hline
\end{tabular}

Data is categorized into three aspects, performance, motivation and job training. Each aspect has three and four subcategories. The total parameter is eleven. Each parameter is filled with the value of the previous score and compared with the existing target value in Table 4 . The gap result after calculation will be in Table 5 .

Table5Gap value

\begin{tabular}{|c|l|c|c|c|c|c|c|c|c|c|c|c|}
\hline \multirow{2}{*}{} & \multirow{2}{*}{ NAME } & \multicolumn{10}{c|}{ ASPECTS } \\
\cline { 3 - 15 } & & \multicolumn{10}{|c|}{ PERFORMANCE } & \multicolumn{3}{c|}{ MOTIVATION } & \multicolumn{3}{c|}{ JOB TRAINING } \\
\hline 1 & EKO & 0 & 1 & -1 & 0 & 2 & 1 & 0 & 0 & 1 & 1 & -1 \\
\hline 2 & BUDI & 1 & 0 & -1 & 0 & 0 & 1 & 1 & 0 & 0 & 1 & -1 \\
\hline 3 & IWAN & -1 & 0 & 1 & 1 & 0 & 2 & 2 & 0 & 0 & 1 & -1 \\
\hline 4 & ANDY & 0 & 1 & -1 & 1 & 1 & 1 & 1 & 0 & 1 & 1 & -1 \\
\hline 5 & DONI & -1 & 0 & 1 & 0 & 0 & 1 & 0 & 0 & 1 & 1 & -1 \\
\hline
\end{tabular}

After the gap values are retrieved, those values will be converted into Profile Matching rule using the gap rule as seen in Table 6 . The Core and Secondary Factors are retrieved from the values by using the earlier formulas. It must have previously determined which are the core factors and secondary factors.

Table6Gap rule

\begin{tabular}{|c|c|}
\hline GAP & VALUE \\
\hline 0 & 4 \\
\hline 1 & 4,5 \\
\hline-1 & 3,5 \\
\hline 2 & 5 \\
\hline-2 & 3 \\
\hline
\end{tabular}


Table7Core Factor and Secondary Factor of Performance

\begin{tabular}{|c|l|c|c|c|c|c|c|}
\hline \multicolumn{2}{|c|}{ WEIGHT } & \multicolumn{3}{|c|}{ PERFORMANCE } & CF & SF \\
\hline 1 & EKO & 4,00 & 4,50 & 3,50 & 4,00 & 4,00 & 4,00 \\
\hline 2 & BUDI & 4,50 & 4,00 & 3,50 & 4,00 & 4,25 & 3,75 \\
\hline 3 & IWAN & 3,50 & 4,00 & 4,50 & 4,50 & 4,00 & 4,25 \\
\hline 4 & ANDY & 4,00 & 4,50 & 3,50 & 4,50 & 4,25 & 4,00 \\
\hline 5 & DONI & 3,50 & 4,00 & 4,50 & 4,00 & 3,75 & 4,25 \\
\hline
\end{tabular}

Table8 Core Factor and Secondary Factor of Motivation

\begin{tabular}{|c|l|c|c|c|c|c|}
\hline \multicolumn{2}{|c|}{ WEIGHT } & \multicolumn{2}{c|}{ MOTIVATION } & CF & SF \\
\hline 1 & EKO & 5,00 & 4,50 & 4,00 & 4,75 & 4,00 \\
\hline 2 & BUDI & 4,00 & 4,50 & 4,50 & 4,25 & 4,50 \\
\hline 3 & IWAN & 4,00 & 5,00 & 5,00 & 4,50 & 5,00 \\
\hline 4 & ANDY & 4,50 & 4,50 & 4,50 & 4,50 & 4,50 \\
\hline 5 & DONI & 4,00 & 4,50 & 4,00 & 4,25 & 4,00 \\
\hline
\end{tabular}

Table9Core Factor and Secondary Factor of Job Training

\begin{tabular}{|c|l|c|c|c|c|c|c|}
\hline \multicolumn{2}{|c|}{ WEIGHT } & \multicolumn{3}{|c|}{ JOB TRAINING } & CF & SF \\
\hline 1 & EKO & 4,00 & 4,50 & 4,50 & 3,50 & 4,00 & 4,25 \\
\hline 2 & BUDI & 4,00 & 4,00 & 4,50 & 3,50 & 4,00 & 4,00 \\
\hline 3 & IWAN & 4,00 & 4,00 & 4,50 & 3,50 & 4,00 & 4,00 \\
\hline 4 & ANDY & 4,00 & 4,50 & 4,50 & 3,50 & 4,00 & 4,25 \\
\hline 5 & DONI & 4,00 & 4,50 & 4,50 & 3,50 & 4,00 & 4,25 \\
\hline
\end{tabular}

Table 7 to 9 are the calculation of all aspects. There are core and secondary factors inside. As the values are obtained, the average value of the ratio of 6:4 (adjustable) between the core and secondary factor is initiated. The following table shows the N1, $\mathrm{N} 2$ and $\mathrm{N} 3$ as the aspect values.

Table10 Aspect Values

\begin{tabular}{|c|l|c|c|c|}
\hline \multicolumn{2}{|c|}{ TOTAL } & N1 & N2 & N3 \\
\hline 1 & EKO & 4,00 & 4,45 & 4,10 \\
\hline 2 & BUDI & 4,05 & 4,35 & 4,00 \\
\hline 3 & IWAN & 4,10 & 4,70 & 4,00 \\
\hline 4 & ANDY & 4,15 & 4,50 & 4,10 \\
\hline 5 & DONI & 3,95 & 4,15 & 4,10 \\
\hline
\end{tabular}

The aspect ratio is $4: 2: 4$ (adjustable). The rank is calculated based on this ratio. The final score is the average of the N1, N2 and N3. Table 11 shows the final score of this case.

Table11Result of Final Score
Table 11 illustrates the results of the final data which have been sorted in descending order. The first row is the highest value. It means the name listed on the first row is the best employee. This method can rank of the specific people to get the particular amount of the best employee as well.

Table12 Descending Order of Final Score

\begin{tabular}{|c|c|c|c|c|c|}
\hline \multirow{2}{*}{ RANKING } & \multicolumn{4}{|c|}{ VALUES } \\
\cline { 3 - 6 } & N1 & N2 & N3 & R \\
\hline 4 & ANDY & 4,15 & 4,50 & 4,10 & 4,20 \\
\hline 3 & IWAN & 4,10 & 4,70 & 4,00 & 4,18 \\
\hline 1 & EKO & 4,00 & 4,45 & 4,10 & 4,13 \\
\hline 2 & BUDI & 4,05 & 4,35 & 4,00 & 4,09 \\
\hline 5 & DONI & 3,95 & 4,15 & 4,10 & 4,05 \\
\hline
\end{tabular}

\section{ConClusion}

Some understanding of the performance of the above it can be concluded that the performance is a feat achieved by a person in carrying out his duties, by criteria set out in the job. This achievement will result in a job satisfaction that will affect the rate of return. To determine the value of achievement required a fast and accurate method. Profile matching method is the correct method used in the valuation of the company's employees. This method can give an idea where the employee is worth keeping and which are not feasible. The benefit given is very helpful to be a reference the owner of the company to raise the reputation of the enterprise.

\section{REFERENCES}

[1] Jogiyanto, Analisis dan Desain Sistem Informasi : Pendekatan Terstruktur, Teori dan Praktek Aplikasi Bisnis, vol. 23, Yogyakarta: Andi Offset, 2005, p. 107-115.

[2] Z. Tharo and A. P. U. Siahaan, "Profile Matching in Solving Rank Problem," IOSR Journal of Electronics and Communication Engineering, vol. 11, no. 5, pp. 73-76, 2016.

[3] A. P. U. Siahaan, "Fuzzification of College Adviser Proficiency Based on Specific Knowledge," International Journal of Advanced Research in Computer Science and Software Engineering, vol. 6, no. 7, pp. 164-168, 2016.

[4] Kusrini, Konsep dan Aplikasi Sistem Pendukung Keputusan, Yogyakarta: Andi Offset, 2007.

[5] D. J. Power, Decision Support Systems : Concepts and Resources For Manager, USA: Greenwood, 2002.

[6] Suwatno and D. J. Priansa, Manajemen SDM Dalam Organisasi Publik dan Bisnis, Bandung: Alfabeta, 2011.

[7] R. L. Mathis and J. H. Jackson, Manajemen Sumber Daya Manusia, Jakarta: Salemba Empat, 2001.

\begin{tabular}{|c|c|c|c|c|c|}
\hline \multirow{2}{*}{ RANKING } & \multicolumn{4}{|c|}{ VALUES } \\
\cline { 3 - 6 } & N1 & N2 & N3 & R \\
\hline 1 & EKO & 4,00 & 4,45 & 4,10 & 4,13 \\
\hline 2 & BUDI & 4,05 & 4,35 & 4,00 & 4,09 \\
\hline 3 & IWAN & 4,10 & 4,70 & 4,00 & 4,18 \\
\hline 4 & ANDY & 4,15 & 4,50 & 4,10 & 4,20 \\
\hline 5 & DONI & 3,95 & 4,15 & 4,10 & 4,05 \\
\hline
\end{tabular}

